Review article

\title{
The application of clinical risk management in hospitals
}

\author{
Radka Prokešová * \\ University of South Bohemia in České Budějovice, Faculty of Health and Social Sciences, Institute of the Humanities in Nursing Professions, \\ České Budèjovice, Czech Republic
}

\begin{abstract}
Clinical risk management (CRM) is a specific method of risk management in hospitals that is directly focused on clinical procedures and indirectly on patient-related procedures. The goal of this study was to summarize the conclusions of the studies that deal with implemented instruments that have helped to decrease or eliminate clinical risk management in hospitals in the last ten years. The included full-text studies were searched for in electronic databases focused on management and healthcare: ECONLIB, ProQuest STM+ Hospital Collection - Medline, Science Direct, Web of Science, PubMed, Scopus and Google Scholar. The full-text studies were searched for after studying their abstracts and relevancy or potential relevancy. The selected studies were searched for using the keywords: management, clinical, risk, monitoring, instrument, hospital, as well as other established criteria (full text, reviewed periodicals, English language) and the publishing period of research conclusions in the last ten years, i.e. 2010-19. We finally included 10 studies that contained the required criteria. The developed CRM instruments are based on the studies of literature and expert knowledge. Hospitals often use existing risk analysis instruments for CRM. For higher efficiency of CRM, it is necessary to identify and analyze individual clinical risks and find suitable solutions. Clinical risks can be decreased by using suitable instruments. The total level of CRM in hospitals is possible to be measured, monitored and regularly assessed, which contributes to its efficiency increase.
\end{abstract}

Keywords: Clinical; Instrument; Hospital; Management; Monitoring; Risk

\section{Introduction}

Risk management in organizations, such as hospitals, is an important everyday issue (Weick and Sutcliffe, 2007) because modern medicine is continuously inclined to more complex treatment methods and care procedures, which improve care but also increase negative-effect risks and patient endangerment. The goal of risk management in hospitals is to eliminate or decrease risk incidence that could have a negative impact on patient and medical staff health as well as the total medical institution (Prokešová et al., 2014). Risk management generally includes political, legal and business environments (Young and Tomski, 2002).

Clinical risk management (CRM) is a specific method of risk management in hospitals that is directly focused on clinical procedures and indirectly on patient-related procedures. Clinical risk management integrates proactive and reactive approaches of risk management and systematically focuses on individuals and the possibilities of their making mistakes (Corrigan et al., 2001; Misson, 2001; Reason, 2002). For this reason, clinical risk management includes all structures, procedures, instruments and activities that enable medical employees to identify, analyze, influence and manage risks during clinical treatment and patient care (Walshe, 2001). The risks related to patient care can never be totally eliminated. For this reason, the key role of clinical risk management is the increase of patient safety (Vincent, 2006).

\section{Materials and methods}

The goal of this study was to summarize the conclusions of the studies that deal with implemented instruments that have helped to decrease or eliminate clinical risk management in hospitals in the last ten years. The included full-text studies were searched for in electronic databases focused on management and healthcare: ECONLIB, ProQuest STM+ Hospital Collection - Medline, Science Direct, Web of Science, PubMed, Scopus and Google Scholar. The full-text studies were searched for after studying their abstracts and relevancy or potential relevancy. The selected studies were searched for using the keywords: management, clinical, risk, monitoring, instrument, hospital, as well as other established criteria (full text, reviewed periodicals, English language) and the publishing period of research conclusions in the last ten years, i.e. 2010-19. The exclusive factor was the realization of clinical risk management outside of hospitals, clinical risk management related only to a specific illness treatment and risk management applied in crisis management. The search method for relevant sources is shown in Chart 1.

\footnotetext{
* Author for correspondence: Radka Prokešová, University of South Bohemia in České Budějovice, Faculty of Health and Social Sciences, Institute of the Humanities in Nursing Professions, J. Boreckého 1167/27, 37011 České Budějovice, Czech Republic; e-mail: rprokes@zsf.jcu.cz; http://doi.org/10.32725/kont.2020.010 


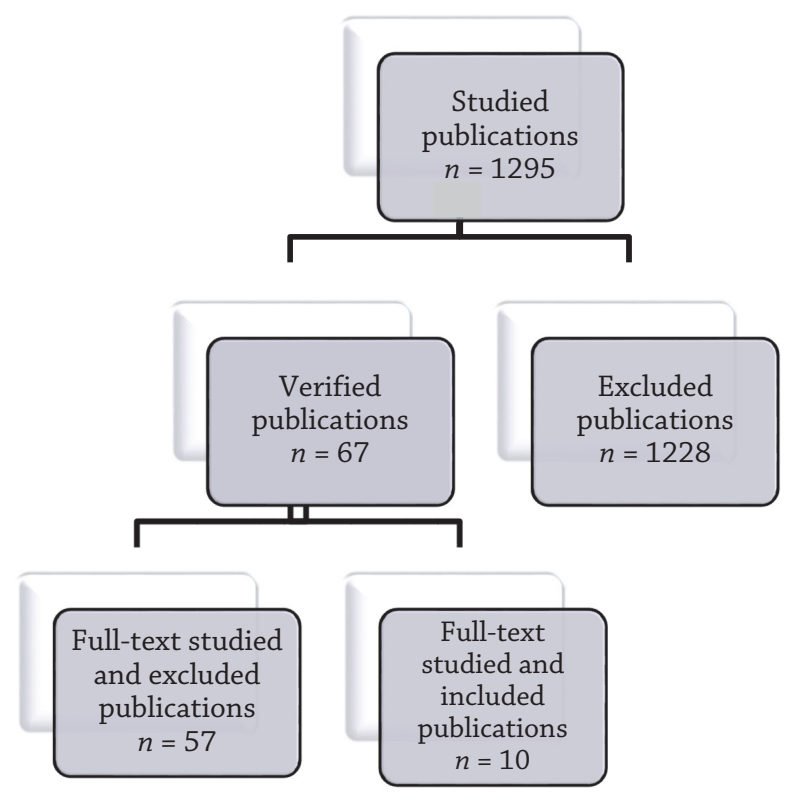

Chart 1. The search methods for relevant sources

\section{Results}

Table 1 includes 10 studies (Bonfant et al., 2010; Briner et al., 2010; 2013; Briner and Manser, 2013; Cagliano et al., 2011; Etges et al., 2018; Farokhzadian et al., 2015a, b; Manser et al. 2017; Rezaei et al., 2013) that deal with clinical risk management in hospitals. 6 of them were interconnected (Briner et al., 2010; 2013; Briner and Manser, 2013; Manser et al., 2017; Farokhzadian et al., 2015a, b). 2 studies (Briner et al., 2010 and Rezaei et al., 2013) dealt with CRM development. Both were primarily based on literary sources and experts' experiences. 3 studies dealt with their application (Briner et al. 2013; Manser et al., 2017; Rezaei et al., 2013). 2 studies dealt with the crucial issue of the CRM list (Cagliano et al., 2011; Etges et al., 2018). 3 studies (Bonfant et al., 2010; Cagliano et al., 2011; Rezaei et al., 2013) used the existing risk analysis methods, whether they were a priori (e.g. the analysis of existent causes/ root cause analysis - RCA) or a posteriori (failure mode and effects analysis - FMEA). One study is oriented to CRM specifics at psychiatric clinics (Briner and Manser, 2013), three studies deal with the assessment of CRM in hospitals (Briner et al., 2013; Farokhzadian et al., 2015a, b) and two studies verify the efficiency of CRM at some hospital departments (Cagliano et al., 2011; Rezaei et al., 2013).

\section{The focus of clinical management risks}

Although literature describes many components and clinical risk management tools, such as control lists, incident report systems, risk assessment methods (Allegranzi et al., 2007; Secker-Walke and Taylor-Adams, 2001), much of this was not known in hospitals (if we are speaking about the total development level of clinical risk management). There were all-state and international studies on quality management and the level of improvement systems of hospital quality (Groene et al., 2009; Lombarts et al., 2009; Makai et al., 2009; Wagner et al., 2006). However, there were no complex studies on CRM (Leape and Berwick, 2005) and key factors that affect CRM levels in hospitals were not known. A breakthrough study regarding clinical risk management was carried out between
2007 and 2008 in 137 Swiss hospitals (Briner et al., 2013). Its goal was to identify key factors that affect clinical risk management in hospitals that would lead to the improvement of medical care regarding this area and increase patient safety. This research was the first to use a complex monitoring tool for clinical risk management, which was based on literature overviews (Briner et al., 2010). This tool provides a more exact outline of clinical risk management regarding hospitals and individual services provided by hospitals. The study of CRM parts was later carried out in Germany and the conclusions were compared (Manser et al., 2017). The authors of previous studies (Briner and Manser, 2013) also dealt with clinical risk management regarding psychiatric institutions. Contemporarily, with the development of new instruments for clinical risk management, the studies of other authors (Bonfant et al., 2010; Cagliano et al., 2011; Rezaei et al., 2013) dealt with the application of instruments and methods that were used in other areas of risk management, such as RCA or FMEA. Such an approach deals with a person's reliability assessment phases so that the human factor is considered in the medical care system. This framework can support effective decision-making about decreasing the number of failures and wasting of resources as well as improving the maturity of healthcare organizations regarding risk management. These studies are related to the studies of authors who used a quantitative approach (Farohkzadian et al., 2015a) and a qualitative approach (Farohkzadian et al., 2015b). Their goal was to assess the CRM condition in Iranian hospitals regarding organizational structure, organizational culture and management challenges regarding nursing. A significant area of CRM was dealt with by Etges et al. (2018), who compiled a list of risks specific to medical institutions. They based it on the identification of the lack of risks in literature and practical cases. The list comprises detailed risk scenarios and their impacts that did not exist at the time of carrying out the research. In the Czech Republic and other countries, this issue has not been studied in detail. Studies include only the risk management issue in hospitals in general (Fialová et al., 2005; Keclíková and Briš, 2011; Prokešová et al., 2014; 2016), which is based on the Luxembourg Declaration on Patient Safety (2016) and supported by the Ministry of Health of the Czech Republic.

\section{The assessment of the CRM focus and achieved CRM effects}

The study published by Briner et al. (2013) was carried out between 2007 and 2008 in Swiss hospitals. It used monitoring instruments that were developed by the research team on the basis of literary research which identified the CRM key elements (Briner et al., 2010). Experts for patient safety later discussed these elements. To describe the implementation of CRM elements in an organization, they used a theoretical model. To review the instruments, they carried out interviews with CRM experts and pilot assessments. The first all-state application of this instrument (138 Swiss hospitals) was supplemented by in-depth interviews with 25 CRM experts in selected hospitals for validation. The monitoring instrument includes 28 main questions in three sections: implementation and organizational CRM integration, strategic goals and CRM operational implementation in hospitals and CRM overview in various services. The instrument is available in four languages (English, German, French and Italian). It enables hospitals to collect complex and systematic data on their practice regarding CRM and identify the areas for further improvement. The instrument was developed for constant monitoring of the development of patient safety. 
Table 1. The researched CRM studies, their focus and achieved effects

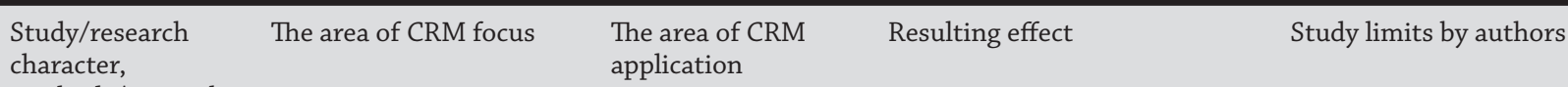

character,

application

methods/research

period

$\begin{array}{ll}\begin{array}{l}\text { Briner et al. (2010) } \\ \text { study - the }\end{array} & \begin{array}{l}\text { The development of the } \\ \text { CRM monitoring tool }\end{array} \\ \text { development of a } & \text { that is based on literary } \\ \text { new instrument, } & \text { research which identified } \\ \text { literary research, } & \begin{array}{l}\text { crucial CRM elements; tool } \\ \text { in-depth interview/ }\end{array} \\ \text { 2007-2008 } & \begin{array}{l}\text { interviewing CRM. }\end{array}\end{array}$

Briner et al. (2010)

- the

new instrument

2007-2008
The complex conception for hospitals and the total systematic data on their practice healthcare system.
The CRM monitoring tool enables The assessment of clinical risk managers in hospitals may vary in the perception of individual medical workers; the contribution of measuring the CRM development phases may be debatable; since the finalization of literature reviews, there have been other publications regarding CRM, i.e. systematic reviews may identify other elements.

Possible bias in self-assessments of risk managers; it is probable that hospitals with a low CRM maturity participated less than hospitals with a high CRM maturity; hospitals in other countries will have to face various challenges; considering the lack of comparable data in Switzerland, the study could not use results to assess the existent patient safety. development.

\section{the areas for improvement. The} monitoring of the development in patient safety.
The complex conception for healthcare system.
Since the finalization of this study, another assessment of hospitals and the total CRM monitoring was carried out in 2010, which enabled the monitoring of new trends

.

\author{
the identification of ke \\ activities that support \\ CRM. \\ lists/2007- 2008 \\ maturity in hospitals \\ and the identification of \\ crucial CRM assumptions; \\ Briner et al. (2013) The assessment of CRM \\ quantitative study of \\ lists/2007- 2008
}

\begin{tabular}{|c|c|}
\hline $\begin{array}{l}\text { Briner and Manser } \\
\text { (2013) } \\
\text { qualitative study - } \\
\text { content analysis }\end{array}$ & $\begin{array}{l}\text { The outline of the main } \\
\text { CRM risk topics in mental } \\
\text { health care and suggested } \\
\text { organizational CRM } \\
\text { procedures that offer a } \\
\text { valuable basis for CRM in } \\
\text { psychiatry and hospitals in } \\
\text { general. }\end{array}$ \\
\hline
\end{tabular}

Briner and Manser (2013) general.

\author{
Psychiatric clinics \\ may use this \\ outline to revise the \\ completeness of their \\ risk assessment and \\ knowledge. \\ The results show CRM specifics \\ in mental health care and provide \\ risk outlines regarding mental \\ health; they can be used to \\ prioritize risks that need to be \\ handled. The CRM procedures \\ in the interviews provide \\ instructions for handling such \\ risks.
}

The results do not have to be generally applied to all types of psychiatric hospitals due to the qualitative approach; the respondents were not fully verbalized; the respondents only mentioned risks in psychiatric hospital departments between reception and discharge.

\footnotetext{
Manser et al. (2017) An empirical comparison of exploratory research, secondary analysis of data from all-state researches in Germany and Switzerland in 2010 incident reporting systems (IRS) in Germany and Switzerland and study of the relationship between the IRS characteristics and contextual factors hospital and CRM characteristics.
}

The complex conception for hospitals.
The study shows the necessity to carefully consider the impact of national healthcare system characteristics in applying their recommendations.
The risk of inaccurate selection and reactions to the IRS characteristics; there were considerable differences in the size of sample groups in each country (in Germany, the sample group was considerably larger).

\section{Fault modes with the} highest RPN were caused by communication and organizational problems. There were two tools created for the improvement of information flow: software "dialysis agenda" and data nursing forms. Planned nephrological examinations and changed medical and nursing organizations. After the re-organization, the total RPN value decreased from 892 to 815 (8.6\%). 
Table 1. (Continued)

\begin{tabular}{|c|c|c|c|c|}
\hline $\begin{array}{l}\text { Study/research } \\
\text { character, } \\
\text { methods/research } \\
\text { period }\end{array}$ & The area of CRM focus & $\begin{array}{l}\text { The area of CRM } \\
\text { application }\end{array}$ & Resulting effect & Study limits by authors \\
\hline $\begin{array}{l}\text { Cagliano et al. } \\
\text { (2011) } \\
\text { qualitative } \\
\text { study/2011 }\end{array}$ & $\begin{array}{l}\text { Applies Reason's theory of } \\
\text { failure in creating system } \\
\text { methodology for risk } \\
\text { studies that directly and } \\
\text { indirectly affect patients; } \\
\text { uses approaches for project } \\
\text { management. }\end{array}$ & $\begin{array}{l}\text { The study provides a } \\
\text { systematic approach } \\
\text { based on expert } \\
\text { knowledge and } \\
\text { possibility to be } \\
\text { improved; its goal } \\
\text { is to provide an } \\
\text { explanation of how it } \\
\text { all works and whether } \\
\text { the methodology } \\
\text { is applicable at } \\
\text { departments of a } \\
\text { large hospital. }\end{array}$ & $\begin{array}{l}\text { The first application to } \\
\text { the logistic process of a } \\
\text { pharmaceutical department in } \\
\text { a large hospital showed that } \\
\text { the method may effectively } \\
\text { support risk analysis as well as } \\
\text { decision making, which increases } \\
\text { the maturity of organizations } \\
\text { regarding clinical risk. }\end{array}$ & $\begin{array}{l}\text { For the full assessment of } \\
\text { the significance for medical } \\
\text { care (proving advantages and } \\
\text { limitations), a widespread } \\
\text { validation in various medical } \\
\text { environments is necessary. }\end{array}$ \\
\hline $\begin{array}{l}\text { Rezaei et al. (2013) } \\
\text { quantitative } \\
\text { and qualitative } \\
\text { study - the method } \\
\text { of focus groups } \\
\text { with inductive } \\
\text { approach, content } \\
\text { analysis/2012-13 }\end{array}$ & $\begin{array}{l}\text { The method was established } \\
\text { in two main stages: the } \\
\text { development of the CRM } \\
\text { initial model during } \\
\text { meetings with experts and } \\
\text { literature revision; after } \\
\text { that, implementation and } \\
\text { verification of the final } \\
\text { model. }\end{array}$ & $\begin{array}{l}\text { The complex } \\
\text { conception for } \\
\text { hospitals developed } \\
\text { for surgical } \\
\text { procedures. }\end{array}$ & $\begin{array}{l}\text { The results of this study showed } \\
\text { that the integrated CRM model } \\
\text { can be used in hospitals as } \\
\text { an effective tool for clinical } \\
\text { management improvement. }\end{array}$ & \\
\hline $\begin{array}{l}\text { Farokhzadian et al. } \\
\text { (2015a) } \\
\text { quantitative } \\
\text { study/2015 }\end{array}$ & $\begin{array}{l}\text { The goal of this study was } \\
\text { to assess the condition of } \\
\text { CRM in hospitals. }\end{array}$ & $\begin{array}{l}\text { The complex } \\
\text { conception for } \\
\text { hospitals. }\end{array}$ & $\begin{array}{l}\text { There were attempts for the } \\
\text { implementation of CRM due to } \\
\text { quality improvement (clinical } \\
\text { management and accreditation) } \\
\text { but thesewere insufficient; } \\
\text { medical care should attempt to } \\
\text { improve quality and safe practice } \\
\text { by effective CRM integration in } \\
\text { the organizational process. }\end{array}$ & \\
\hline $\begin{array}{l}\text { Farokhzadian et al. } \\
\text { (2015b) } \\
\text { qualitative study - } \\
\text { content analysis, } \\
\text { semi-structured } \\
\text { interviews/2015 }\end{array}$ & $\begin{array}{l}\text { The goal of this research } \\
\text { was to study the } \\
\text { experiences of nurses with } \\
\text { the challenges of CRM } \\
\text { implementation regarding } \\
\text { an organization. }\end{array}$ & $\begin{array}{l}\text { The complex } \\
\text { conception for } \\
\text { hospitals. }\end{array}$ & $\begin{array}{l}\text { Regarding organization related } \\
\text { to the appropriateness of medical } \\
\text { care in Iran, there are obvious } \\
\text { needs to improve the quality and } \\
\text { safety measures by effective CRM } \\
\text { implementation. }\end{array}$ & $\begin{array}{l}\text { This study was part of a larger } \\
\text { study that was carried out to study } \\
\text { CRM in nursing. }\end{array}$ \\
\hline $\begin{array}{l}\text { Etges et al. (2018) } \\
\text { quantitative } \\
\text { and qualitative } \\
\text { study - descriptive } \\
\text { statistics, in-depth } \\
\text { interviews, cluster } \\
\text { analysis/2017 }\end{array}$ & $\begin{array}{l}\text { To develop a list of } 28 \\
\text { company risks for medical } \\
\text { organizations and describe } \\
\text { their specific scenarios. }\end{array}$ & $\begin{array}{l}\text { The complex } \\
\text { conception for } \\
\text { hospitals. }\end{array}$ & $\begin{array}{l}\text { Specific characteristics of } \\
\text { hospitals, such as time period of } \\
\text { risk management, the size of the } \\
\text { organization and the presence of } \\
\text { medical faculties, which, based } \\
\text { on the results of the study, do } \\
\text { not affect individual opinions } \\
\text { on the significance of identified } \\
\text { risks. }\end{array}$ & \\
\hline
\end{tabular}

A cross-sectional study that used this complex monitoring instrument was carried out in 324 Swiss hospitals. Its goal was to assess the relationship between key elements and systematic CRM. The key elements tested organizational factors (e.g. strategies, co-ordination, sources) and structural conditions (e.g. hospital size). CRM was assessed by its maturity (i.e. CRM development level) and 12 theoretically derived indexes that connect the basic CRM aspects in hospitals and the levels of provided services. The participation in this voluntary research was good - 138 CRM experts from 324 hospitals responded
(43\%). The research identified three key assumptions for CRM: function implementation for central CRM co-ordination, ensuring interviews in various hospital services and between them, and the development of CRM strategic goals. This study is the first to assess CRM maturity in hospitals and identifies key assumptions regarding CRM. This presents a realizable first step in forming CRM in hospitals as well as the basis for further studies, such as associating CRM with other hospital data. 
The study of CRM parts was later also carried out in Germany and the results were compared (Manser et al., 2017). The goal of this study was to empirically compare incident reporting systems (IRS) in two European countries and study the relationship between IRS characteristics and context factors, such as hospital characteristics and CRM characteristics. This study was a secondary analysis of data from all-state researches carried out in Germany and Switzerland in 2010. Originally, the research was sent to 2,136 hospitals. It was found that both samples that were used in this new analysis were representative of the state system of hospital care in previous studies. Compared to the involved hospitals in other countries, Swiss hospitals implemented the IRS sooner and systematically provided IRS introductory courses more often. German hospitals more frequently systematically implemented standardized adverse event analysis methods. IRS characteristics were significantly associated with hospital characteristics (hospital type) and CRM characteristics (the existence of CRM strategic goals in hospitals and established work positions for CRM central co-ordination). The results of the second study offered new possibilities for empirically strategic interventions whose goal was to improve the spreading of the IRS and support hospitals in their effort to move forward regarding patient safety.

This research is also followed by a qualitative content analysis from psychiatric institutions (Briner and Manser, 2013). This qualitative study provides an overview of the most significant clinical risks regarding mental health and associated methods of organization management. They carried out indepth interviews with professionals who are responsible for CRM in psychiatric institutions. These interviews were put in writing and analyzed using a qualitative content analysis regarding the classification of identified risks. The conclusions of this study show that the main CRM concerns regarding mental health are violence and self-destructive behaviour, mistakes regarding treatment and risks associated with mental illnesses. This study identified critical differences in CRM in hospitals regarding CRM specifics in mental health because many psychiatric patients do not believe that they are ill, thus they are in the hospital against their will, and the safety of the employees is a much more important topic of CRM regarding the care of mental health because it is associated with the specifics of mental illnesses.

The research of Bonfant et al. (2010) regarding the application of CRM used FMEA, which is used for risk decrease. FMEA was applied at nephrology and dialysis departments in the Italian Regional Hospital of Aosta. FMEA was carried out in May and July 2007. Reorganizational plans have been used since August 2007 and audits were carried out after 2, 4 and 10 months. The following steps of FMEA were carried out: process study, danger analysis, planning and monitoring. Failure modes with risk priority numbers (RPN) were caused by communication and organizational problems. They created two instruments to improve information flow: software "dialysis agenda" and nursing data forms. They planned examinations in nephrology and changes in medical and nursing task organization. After the reorganization, the total RPN value decreased from 892 to 815 (8.6\%). After FMEA was applied, some critical activities were adjusted and patient clinical risk was decreased. The priority matrix also considered the importance of control measures - this assessment is quick due to a simple priority selection and shortens the times of actions.

The study of Cagliano et al. (2011) regarding CRM application in hospitals used the Reason's failure model (Reason, 2002) to develop system methodology for risk studies that directly and indirectly affect patients. Research methodology uses approaches for the management of projects, risks and their impacts that enable system risk analysis-which is not possible if these approaches are applied separately. For this reason, the authors designed a methodology that is structured in four progressive steps: context analysis, trial mapping, risk identification and assessment, and FMEA. The study includes the designed methodology and its application including the advantages and limitations of the approach and future researches. The developed methodology was applied at the department of pharmacy of a large hospital with 1,372 beds and 5,822 employees in Torino. The first application on the logistic process of the pharmacy department in a large hospital emphasized that the method can effectively support not only a risk analysis but also decision making - which increases organization maturity regarding clinical risks. A widespread validation in medical environments is required to fully show the advantages and limitations.

The goal of the study of Rezaei et al. (2013) was to develop a complex instrument that could decrease the limitations of individual instruments for risk assessment and management. This study is quantitative and qualitative. From the qualitative point of view, the method of focus groups with the inductive approach is used. For the assessment of the conclusions of the qualitative study, they carried out a quantitative evaluation. First, they carried out purpose-built and stratification samples of various responsible teams for the selected process. The final model was verified in eight phases using the mapping of the selected process (according to one of the project management instruments), FMEA, RPN, RCA, disorders diagram and Eindhoven classification model. This model was usually carried out in patients who were admitted at the surgical clinical department of a public hospital between October 2012 and June 2013. The qualitative data analysis was carried out using content and quantitative analyses that used RPN control lists and adjusted tables. After verifying the final model in eight steps, the process of admitting patients for surgery was created by the members of the focus group in five main phases. After accepting the FMEA methodology, the tables included 85 failure modes and their causes, consequences and the possibilities of preventative disclosure. After three months, the most frequently reported events were cases of wrong patient identification. After giving preference to suggested interventions, a computer registration system in the medication system was accepted. In the final phase, it enabled preparing the plan of actions. The complexity of healthcare requires risk managers to have a versatile vision. The results of this study showed that the CRM integrated model in hospitals can be used as an effective instrument for the improvement of clinical management.

The goal of the study of Farohkzadian et al. (2015a) was to assess the condition of CRM in hospitals. 200 nursing employees from three faculty hospitals associated with the Iran University of Medical Sciences in Kerman participated in this cross-sectional study. The data were collected using a questionnaire and observation control list in offices to improve the quality at selected departments. The data were analyzed using SPSS 20. The results of the study showed that almost $57 \%$ of the people had finished at least one CRM training. The condition of the CRM system assessment was based on research results. In the six domains of the CRM system, the highest average was in analysis monitoring, assessment and risk control; the lowest average was found in the knowledge of employees, recognizing and understanding CRM. The qualitative study of Farohkzadian et al. (2015b) was a part of the previous larger study that was carried out to study CRM processes in nursing. It dealt with the application of CRM and its goal was to 
study the experiences of nurses with CRM implementation regarding an organization. The study was based on conventional content analysis. It was carried out to study the experiences of nurses with CRM implementation in faculty hospitals in Kerman, Iran, and the challenges of the implementation. In this part of the study, the researchers used the conventional qualitative method of content analysis to identify the experiences of the participants with organizational problems during CRM implementation. The participants were selected using purpose-built sampling. For the collection of data, the authors used semi-structured interviews and document revisions. The data analysis included three categories that (together with their subcategories) explained the challenges associated with CRM implementation, i.e. organizational culture and management challenges, source limitations and the complexity of work conditions.

The goal of the study of Etges et al. (2018) was to develop a register of company risks for medical organizations to create a common understanding of the influences or each risk type on a medical organization. Before creating the register of risks, they analyzed the instructions and the data from 15 interviews with managers regarding risks. The risks found were confirmed by the survey of risk managers from a number of medical institutions during the ASHRM conference in 2014 (ASHRM, 2014). Descriptive statistics were developed and cluster analysis was carried out using the survey. The resulting list of risks includes 28 risks and their specific scenarios. The main risks were cybernetic attacks and risks associated with the management of capital. Securing patient data in hospitals that work with high technology is fundamental for providing high-quality and safe patient care. The data analysis showed that specific characteristics of research participants such as time, organization size and the presence of a medical faculty do not affect individual opinions on the significance of identified risks. From the point of view of personal experience in risk management (clinical or company risks), there was a small difference in the perceived importance of risks from the suggested list of risks. Besides defining specific risk scenarios, the list of organization risks in this study can contribute to the management of risk identification regarding company risks and support the development of risk culture. Suggestions for future studies are studying the opportunity of improving cybernetic risk management and the assessment of advantages that arise from the use of the list of risk at the beginning of risk identification regarding company risks.

\section{Discussion}

The included articles in this review (Table 1) are focused on clinical risks that are labelled as clinical errors, which are different from intended treatment, care, therapeutic interventions or diagnostic results (Sale, 2005). They are also labelled as probabilities that patients are voluntarily or involuntarily affected by adverse events that were caused by medical treatments (Kohn et al., 1999). Clinical risks can be caused by many factors in systems; the environment and the individual interplay in processes related to care provision. In this context, it is a wider view of clinical risks, including all incidents that can, directly and indirectly, affect patient safety. This shows a strong need for understanding mistakes and their correlation by working on their causes (Cagliano et al., 2011).

Despite all of the programmes, initiatives and instruments that can be considered CRM elements, hospitals lack knowledge on their implementation (Briner et al., 2010). CRM should be a long-term issue that shows progress. For this reason, it is suitable to regularly monitor and assess its level. Two of the mentioned studies (Briner et al., 2010; Rezaei et al., 2013) deal with the development of CRM tools. Both are primarily based on literature and expert experiences in this area. Both instruments were centrally constructed, i.e. for CRM in organizations. Both developed instruments use a system approach and link various management areas that are applied in hospitals.

The monitoring instrument that was developed by the Swiss scientific team of Briner et al. (2010) provides a few advantages in hospitals and state organization. It enables hospitals to achieve complex and systematic data on their CRM by individually assessing every participating hospital. They emphasized the responses of hospitals to identify the hospital's location and gain the CRM profile that would show the hospital's strong and weak sides. This profile can help with establishing priorities, development and interventions that are adjusted to the development stages of a specific hospital. The possibility to assess and continuously monitor CRM elements, and exchange and compare them in similar type hospitals can be supported by learning and sharing the correct CRM methods. Furthermore, feedback enables the support of the CRM action plan because of its systematic approach. Monitoring instruments can also manage CRM development. This monitoring instrument was later used for CRM research in Swiss and German hospitals. Parts of the research results were compared (Manser et al., 2017), especially regarding incidence report systems (IRS). If a report was anonymous, there were significant differences in the Swiss sample group of hospitals, where psychiatric institutions more frequently enabled identifiable reports but ensured confidentiality. In Europe, there is no documentation of dealing with anonymous vs. confidential reports (European Commission, 2014). Briner and Manser (2013) also dealt with a special CRM area - psychiatric institutions. They mostly mention the risk of self-destructive behaviour (mainly suicides and attempts to commit suicide) and violence/aggression towards others. From the point of view of CRM, it means that the main goal is patient and personnel protection from other patients and patients from themselves. Professional interventions can decrease violence in many cases. To achieve this goal, it is important to use sensitization, education and the expert preparation of staff and preventative instruments to predict violence. These are the other main reasons that CRM in mental health care needs specialized concepts and strategies that supplement the knowledge of CRM in medical care.

Another CRM instrument that was developed by the Iranian scientific team of Rezaei et al. (2013) is a complex instrument that can supplement other instruments for risk assessment and management that have limitations. It was developed using a selected process. They agreed on the process from hospitalization admission to discharge from a surgical department (the control list had five phases - from pre-operation examination to pre-discharge examination but the last phase was removed from the study because most possible failure regimes could be included in the transfer phase). The control list of the WHO surgical safety (2008) also considered surgical processes in operating theatres and the members of surgical and anaesthetic teams are, as a target group, relevant for filling in the control list. Therefore, the study is different from the WHO vision due to the use of a wider concept of the surgical process.

The assessment of CRM condition in hospitals was also the goal of the studies of Farohkzadian et al. (2015 a, b). The cross-section quantitative study (Farohkzadian et al., 2015 a) included 200 nursing employees from the Iran University of 
Medical Sciences in Kerman. The complementary qualitative study (Farohkzadian et al., 2015 b) was focused on studying CRM processes in nursing. Its goal was to study the experiences of nurses regarding the challenges of CRM implementation in an organization. The conclusions of both studies recommend integrating $\mathrm{CRM}$ in the organizational process to increase the quality of hospitals.

An important basic part of risk management is the list of possible risks. This list regarding CRM in hospitals is most dealt with by Cagliano et al. (2011) and Etges et al. (2018). The study of Cagliano et al. (2011) is based on the risk management of project management that deals with planning, identifying, analyzing, reactions, monitoring and controlling risks. Risk management applied in project management was accepted to cover all health risks - clinical and non-clinical. The study also develops a systematic methodology and uses the Reason's failure model (Reason, 2002) and methods for project, risk and discard management, which enables them to contribute to the system risk analysis. The results of the study based on the system approach that is founded on expert knowledge enable the permanent improvement of CRM in an organization. The research results were the basis for the creation of two instruments for the improvement of information flow: the "dialysis agenda" software and nursing data forms. The created methodology was successfully applied in the department of pharmacy in a large Italian hospital.

The team of Brazilian authors Etges et al. (2018) succeeded in developing a list of 28 company risks for healthcare organizations and the list of their specific scenarios. 26 of them can affect patient care or their families. Healthcare organizations must carry out transparent procedures that include clinical impacts of risks regardless of whether the initial risk event was clinical. This approach would help patient care and their experiences to focus on the management of a strategic decision-making process. The number one company risk in healthcare organizations was cybernetic attacks. The last report by Aon Inpoint (2017) implies that more and more healthcare organizations are investing in the protection of sensitive information about patients. The main reason is the General Data Protection Regulation (GDPR) and medical information protection, which the organization is responsible for.

In CRM, the studied papers (Bonfant et al., 2010, Cagliano et al., 2011; Rezaei 2013) also use the existing methods for risk analysis - a priori (e.g. RCA) or a posterior (FMEA). The application of FMEA in medicine that was related to methodical aspects, the use of clinical equipment and providing therapy, were dealt with by a few older studies (Duwe et al., 2005; Krouwer, 2004, van Tilburg et al., 2006; Woodhouse et al., 2004). Bonfant et al. (2010) used FMEA to analyze the total complex process of haemodialysis. Farokhzadiana et al. (2015 b) studied the experiences of nurses that were related to CRM implementation challenges in an organization in nursing plans in Iran. For this reason, the authors thought it was necessary to study the ways of proposing nursing plans so that it is possible to include various CRM aspects and patient safety in curriculums.

\section{The limitations of the study}

This paper provides an overview of research results regarding CRM in hospitals. A limitation can be the inclusion of papers that are written only in English: we have not included studies written in other languages. Another limitation is the level of evidence that was included in this overview. The results can be limited by frequently applied CRM regarding specific illnesses. The authors of the studies included in this overview see the limitations of their studies in e.g. restricting their research to one hospital type or department - the results cannot be globalized - or limitations arising from comparing CRM in different countries. Another limitation is the selection of keywords for the database search, which were connected to the Boole operator "and" - we found a large number of irrelevant sources. Another limitation was the time interval when the studies were searched for.

\section{Conclusions}

CRM plays a key role in enabling hospitals to identify, decrease and manage risks regarding patient safety. This study summarizes the conclusions of the researches found on implemented management instruments and methods that have led to the decrease or elimination of clinical risk management in hospitals in the last ten years. Based on the studied researches, CRM is a systematic issue that is dealt with centrally regarding the management of hospitals and individual organizational hospital units. The developed instruments are based on the study of literature and expert knowledge. Hospitals often use existing risk analysis instruments for CRM (RCA, FMEA). Using only one of the a priori or a posteriori instruments for risk management does not bring expected effects. Other instruments that lead to the improvement of CRM in hospitals are software and data forms. It is possible to use methods from other parts of management to make CRM more effective, such as project and process management or risk and discard management - which also contributes to the system risk analysis. To make CRM more effective, it is necessary to analyze individual risks and create suitable scenarios for their solution. The lists of risks also proved to be effective. Based on the results of studies for the improvement of quality and safe practice in hospitals, the inclusion of CRM in organizational processes is very positive. The level of CRM in hospitals is possible to be measured, monitored and regularly assessed, which contributes to the increase in their effectiveness.

\section{Conflicts of interests}

The author has no conflict of interests to declare.

\section{Acknowledgements}

This paper is supported by the Faculty of Health and Social Sciences of the University of South Bohemia in Česke Budějovice. It is a part of the FHSS individual project and internal research entitled: "The Use of Clinical Risk Management in Czech Hospitals" and is financed by the FHSS RVO. 


\section{Aplikace managementu klinických rizik v prostředí nemocnic}

\section{Souhrn}

Klinické řízení rizik (CRM) je specifickou formou řízení rizik v nemocnicích, které je zaměřeno přímo na klinické procesy a nepřímo na procesy související s pacientem. Cílem přehledové studie bylo shrnout závěry výzkumů o zavedených nástrojích vedoucích ke snížení či eliminaci řízení klinických rizik v prostředí nemocnic za uplynulých deset let. Zařazené články byly vyhledány v plnotextových elektronických databázích zaměřených na management a zdravotnictví: ECONLIB, ProQuest STM+ Hospital Collection - Medline, Science Direct, Web of Science a dále citačních: PubMed, Scopus a Google Scholar, plné texty článků byly dohledány po prostudování abstraktů a po zhodnocení jako relevantní nebo potencionálně relevantní zdroj. Vybrané studie byly vyhledány pomocí klíčových slov: management, clinical, risk, monitoring, instrument, hospital a dále dle dalších stanovených kritérií (plný text, recenzovaná periodika, anglický jazyk) a období publikace výsledků výzkumu posledních deseti let, tedy 2010-19. Do konečného přehledu bylo zařazeno 10 studií, které splnily požadovaná kritéria. Vyvinuté nástroje CRM vycházejí ze studia literatury a expertních znalostí. Často jsou však v prostředí nemocnic pro oblast CRM využívané již existující nástroje analýzy rizik. Pro dosažení vyšší efektivity CRM je nutné jednotlivá klinická rizika identifikovat, analyzovat a vytvářet k nim vhodné scénáře řešení. Klinická rizika je možno s využitím vhodných nástrojů prokazatelně snižovat. Celkovou úroveň CRM v nemocnicích je možné měřit, sledovat a pravidelně vyhodnocovat, což nepochybně přispívá ke zvýšení její efektivity.

Klíčová slova: klinický; management; nástroj; nemocnice; riziko; sledování

\section{References}

1. Allegranzi B, Stor, J, Dziekan G, Leotsakos A, Donaldson L, Pitte D (2007). The first global patient safety challenge 'clean care is safer care': from launch to current progress and achievements. J Hosp Infect 65(Suppl. 2): 115-123. DOI: 10.1016/S0195-6701(07)60027-9.

2. Aon Inpoint (2017). Global Cyber Market Overview. [online] [cit. 2019-12-31]. Available from http://www.aon.com/ attachments/risk-services/cyber/Cyber.pdf

3. ASHRM (2014). Enterprise risk management. Framework Success 6:53-73.

4. Bonfant G, Belfanti P, Paternoster G, Gabrielli D, Gaiter AM, Manes M, et al. (2010). Clinical risk analysis with failure mode and effect analysis (FMEA) model in a dialysis unit. J Nephrol 23(1): 111-118.

5. Briner M, Manser T (2013). Clinical risk management in mental health: a qualitative study of main risks and related organizational management practices. BMC Health Serv Res 13:44. DOI: 10.1186/1472-6963-13-44.

6. Briner M, Kessler O, Pheiffer Y, Wehner T, Manser T (2010). Assessing hospitals' clinical risk management: Development of a monitoring instrument. BMC Health Servi Res 10: 337. DOI: 10.1186/1472-6963-10-337.

7. Briner M, Manser T, Kessler O (2013). Clinical risk management in hospitals: strategy, central coordination and dialogue as key enablers. J Eval Clin Pract 19(2) 363-369. DOI: 10.1111/j.13652753.2012.01836.x.

8. Cagliano AC, Grimaldi S, Rafele C (2011). A systemic methodology for risk management in healthcare sector. Safety Science 49(5): 695-708. DOI: 10.1016/j.ssci.2011.01.006.

9. Corrigan JM, Donaldson MS, Kohn LT, Maguire SK, Pike KC (2001). Crossing the quality chasm: A new health system for the 21st century. Washington, D.C. National Academy Press.

10. Duwe B, Fuchs BD, Hansen-Flashen J (2005). Failure mode and effects analysis application to critical care medicine. Crit Care Clin 21(1): 21-30. DOI: 10.1016/j.ccc.2004.07.005.

11. European Commission (2014). Key findings and recommendations on: Reporting and learning systems for patient safety incidents across Europe. [online] [cit. 2020-0110]. Available from http://buonepratiche.agenas.it/documents/ More/8.pdf

12. Etges APBDS, Grenon V, Lu M, Cardoso RB, de Souza JS, Kliemann Neto FJ, Felix EA (2018). Development of an enterprise risk inventory for healthcare. BMC Health Serv Res 18(1): 578. DOI: 10.1186/s12913-018-3400-7.
13. Farokhzadian J, Dehghan Nayeri N, Borhani F (2015a). Assessment of clinical risk management system in hospitals: an approach for quality improvement. Glob J Health Sci, 7(5): 294-303. DOI: 10.5539/gjhs.v7n5p294.

14. Farokhzadian J, Dehghan Nayeri N, Borhani F (2015b). Rocky milieu: challenges of effective integration of clinical risk management into hospitals in Iran. Int J Qual Stud Health Wellbeing 10:27040. DOI: 10.3402/qhw.v10.27040.

15. Fialová D, Topinková E, Gambassi G (2005). Potentially inappropriate medication use among elderly home care patients in Europe. JAMA 293(11): 1348-1358. DOI: 10.1001/ jama.293.11.1348.

16. Groene O, Klazinga N, Walshe K, Cucic C, Shaw CD, Sunol R (2009). Learning from MARQuIS: future direction of quality and safety in hospital care in the European Union. Qual Saf in Health Care 18(1): 69-74. DOI: 10.1136/qshc.2008.029447.

17. Keclíková K, Briš P (2011). Risk management and internal audit in integrated process management of hospitals. Ekonomie a Management 14(4): 55-66.

18. Kohn LT, Corrigan JM, Donaldson MS (1999). To err is human: building a safer health system. Washington, D.C. National Academy Press.

19. Krouwer JS (2004). An improved failure mode effects analysis for hospitals. Arch Pathol Lab Med 128(6): 663-667.

20. Leape LL, Berwick DM (2005). Five years after To Err Is Human: what have we learned? JAMA 293(19): 2384-2390. DOI: 10.1001/jama.293.19.2384.

21. Lombarts MJ, Rupp I, Vallejo P, Sunol R, Klazinga NS (2009). Application of quality improvement strategies in 389 European hospitals: results of the MARQuIS project. Qual Saf Health Care 18(1): 28-37. DOI: 10.1136/qshc.2008.029363.

22. Luxembourg Declaration on Pacient Safety (2016). Patient Safety - Making it Happen! [online] [cit. 2019-16-12]. Available from: http://ec.europa.eu/health/ph_overview/Documents/ ev_20050405_rd01_en.pdf

23. Makai P, Klazinga N, Wagner C, Boncz I, Gulacsi L (2009). Quality management and patient safety: survey results from 102 Hungarian hospitals. Health Policy 90(2-3): 175-180.

24. Manser T, Imhof M, Lessing C, Briner M (2017). A crossnational comparison of incident reporting systems implemented in German and Swiss hospitals. Int J Qual in Health Care 29(3): 349-359. DOI: 10.1093/intqhc/mzx030.

25. Misson JC (2001). A review of clinical risk management. J Qual Clin Pract 21(4): 131-134. DOI: 10.1046/j.14401762.2001.00421.x.

26. Prokešová R, Brabcová I, Bártlová S, Tóthová V (2014). Specifics of risk management in select medical facility. Kontakt 16(4): 256-262. DOI: 10.1016/j.kontakt.2014.10.004. 
27. Prokešová R, Brabcová I, Pokojová R, Bártlová S (2016). Risk management in inpatient units in the Czech Republic from the point of view of nurses in leadership positions. Neuro Endocrinol Lett 37(2): 39-45. PMID: 28233959.

28. Reason J (2002). Combating omission errors through task analysis and good reminders. Qual Saf Health Care 11(1): 40-44. DOI: 10.1136/qhc.11.1.40.

29. Rezaei F, Yarmohammadian MH, Ferdosi M, Haghshenas A (2013). Developing an integrated clinical risk management model for hospitals. Int J Health Syst Disaster Manage 1(4): 221-228. DOI: 10.4103/2347-9019.130740.

30. Sale D (2005). Understanding clinical governance and quality assurance. New York: Palgrave Macmillan.

31. Secker-Walker J, Taylor-Adams S (2001). Clinical incident reporting. In: Vincent C, Williams J (Eds). Clinical risk management: enhancing patient safety, 2nd ed. London: BMJ Books, pp. 419-438.

32. van Tilburg CM, Leistikow IP, Rademaker CM, Bierings MB, van Dijk AT (2006). Health care failure mode and effect analysis: a useful proactive risk analysis in a pediatric oncology ward. Qual Saf Health Care 15(1): 58-63. DOI: 10.1136/qshc.2005.014902.

33. Vincent C (2006). Patient safety. Edinburgh: Elsevier Churchill Livingstone.
34. Wagner C, Gulacsi L, Takacs E, Outinen M (2006). The implementation of quality management systems in hospitals: a comparison between three countries. BMC Health Serv Res 6: 50. DOI: 10.1186/1472-6963-6-50.

35. Walshe K (2001). The development of clinical risk management. In: Vincent C, Williams J (Eds). Clinical risk management: enhancing patient safety, 2nd ed. London: BMJ Books, pp. 45-60.

36. Weick KE, Sutcliffe KM (2007). Managing the unexpected. Resilient performance in an age of uncertainty, 2nd ed. San Francisco: Jossey-Bass.

37. WHO (2008). Surgical safety checklist. [online] [cit. 202001-11]. Available from: https://www.who.int/patientsafety/ safesurgery/checklist/en/

38. Woodhouse S, Burney B, Coste K (2004). To err is human: improving patient safety through failure mode and effect analysis. Clin Leadersh Manag Rev 18(1): 32-36. PMID: 14968751.

39. Young PC, Tomski M (2002). An introduction to risk management. Physical medicine and rehabilitation clinics of North America 13(2): 225-246. 